\title{
Lietuvos saugumo ir gynybos politika: raida ir perspektyvos
}

\begin{abstract}
Straipsnyje analizuojant Lietuvos saugumo ir gynybos politikos raidą nuo 1990 $\mathrm{m}$. iki šių dienų mėginama apibrèžti jos pagrindines tendencijas ir perspektyvas. Lietuvos saugumo ir gynybos politikai didžiausią įtaką turèjo valstybingumo įtvirtinimo ypatybès. Atsikūrusi Lietuvos valstybẻ turëjo užtikrinti ne tik valstybės suvereniteto išsaugojimą, bet ir sudaryti palankias sąlygas esminiams teisiniams ir ekonominiams pokyčiams. Šiems sudètingiems uždaviniams igyvendinti buvo pasirinktas narystės NATO ir ES kelias. Narystės šiose organizacijose kriteriju tenkinimas bei derybu procesas vedẻ prie visapusiškos valstybės ir visuomenès transformacijos. Saugumo politikoje tai skatino negatyvių nuostatu kaimyninių valstybių atžvilgiu įveikimą bei perèjimą prie bendro saugumo sampratos. Šie procesai lèmè pokyčius gynybos politikoje, perëjimą nuo teritorinès prie kolektyvinės gynybos koncepcijos bei ginkluotuju pajėgų reformą. Tapusi ES ir NATO nare, Lietuva imasi ambicingo lyderės vaidmens, skleisdama politinių ir ekonominiu reformų patyrimą į kaimynines rytu šalis. Lietuva palaiko karinės ES dimensijos stiprinimą, tačiau nepritaria galimam ES ir NATO funkcijų ir pajégumų dubliavimui, savo saugumą siedama su tvirto transatlantinio ryšio išlaikymu.
\end{abstract}

\section{Ivadas}

Lietuva, $2004 \mathrm{~m}$. tapusi ES ir NATO nare, siekia aktyviai įsijungti ị abieju instituciju veiklą. Ji pirmoji $2004 \mathrm{~m}$. ratifikavo ES konstitucijos projektą bei buvo tarp pirmuju naujujų valstybių, siekiančių prisijungti prie euro zonos. Ir jos gyventojai, ir politinis elitas teigiamai vertina Lietuvos narystę ES ir NATO bei jos tolimesnes perspektyvas. Galima teigti, kad 1994 m. ryžtingai pasukusi į Vakarus, Lietuva pasirinko optimalią užsienio ir saugumo politikos krypti, atitinkančią jos gyventojų lūkesčius. Tačiau ar šie optimistiniai teiginiai neskamba kaip savotiškas ,,istorijos pabaigos“ (valstybès - GM) konstatavimas? Ar nevirsta suvereni valstybė tik ES fondu naudotoja bei stropia ES ir NATO direktyvų vykdytoja? Ar buvimas ES erdvëje palieka vietos savarankiškoms Lietuvos užsienio ir saugumo politikos iniciatyvoms? Šie įvairaus lygio debatuose plačiai aptarinejjami klausimai yra ypač aktualūs nagrinejjant Lietuvos saugumo ir gynybos politikos (LSGP) santykị su Europos Sajungos saugumo ir gynybos politika (ESGP) ir NATO.

* Doc. Dr. Gražina Miniotaitè - Lietuvos karo akademijos Politikos mokslų katedros profesoré, Kultūros, filosofijos ir meno instituto vyresnioji mokslo darbuotoja. Adresas: Šilo g. 5a, 10322 Vilnius, tel. 8-5 2103569, el.paštas grazina.m@gmail.com 
Tam tikrą atsakymą i šiuos klausimus galima rasti oficialiose pareigūnu kalbose bei saugumo politikos tekstuose, kuriuose pabrèžiama, kad Lietuva santykiuose su ES ir NATO siekia tapti „ne tik naudotoja, bet ir pagalbininke ${ }^{{ }_{11}}$. Kyla klausimas, ar pagrista tokia Lietuvos SGP charakteristika, ar tai tik tolimos perspektyvos tikslus išreiškiantis šūkis? Kokị tarptautinį valstybės identitetą kuria ši ambicinga LSGP nuostata? Kaip ji atsispindi konkrečiuose politiniuose sprendimuose? Paméginsiu atsakyti i šiuos klausimus, nagrinėdama Lietuvos saugumo politikos evoliuciją bei pagrindines pastarujų metų LSGP tendencijas.

Straipsnyje LSGP analizė daugiausiai grindžiama konstruktyvistine saugumo samprata, kurioje pabrěžiamas vadinamų nematerialių faktorių (ideju, identiteto, vertybiu, istorinių mitų ir t. t.) vaidmuo užsienio ir saugumo politikoje. Klaidinga būtų manyti, kad konstruktyvizmas, aiškinant valstybiu elgesi, apskritai neigia objektyviu aplinkybiu svarbą. Lietuva dar ilgai išliks „svarbiausia kontakto zona“2 tarp Rusijos ir Europos Sajungos, tačiau, konstruktyvizmo požiūriu, santykiai su Rusija (kaip ir bet kuria kita valstybe) nèra aplinkos sąlygotas dalykas, o kinta priklausomai nuo idejjiniu faktorių kaitos. Remiantis ankstesnių tyrimų rezultatais ${ }^{3}$, galima teigti, kad Lietuvos politikoje naudojama saugumo samprata yra artima Barry Buzano suformuluotam saugumo apibrèžimui: saugumas yra „valstybių ir visuomeniu sugebẻjimas išsaugoti savo nepriklausomą identitetą ir funkcinį integralumą prieš pakitimu jẻgas, kurias jos laiko priešiškomis“4.

Šiame apibrěžime susipina dvi pagrindinès tarptautinių santykių analizès paradigmos - realizmas ir konstruktyvizmas. Realizmas saugumą supranta objektyvistiškai - kaip tam tikrą objektyviai siektiną būseną. Atitinkamai tautinis identitetas apibrèžiamas kaip natūraliai egzistuojanti duotybè, o jo apsauga - kaip svarbiausias valstybės užsienio ir saugumo politikos uždavinys 5 . Tačiau grèsmès („pakitimu jègos, kurias jos (valstybės - G. M.) laiko priešiškomis“) suprantamos intersubjektyviai - kaip socialinis konstruktas. Vèliau ši antroji saugumo sampratos dalis buvo išplèsta bendruose Buzano ir Ole Wæverio darbuose ir tapo žinoma kaip saugumizavimo (securitization) teorija ${ }^{6}$. Suprastintai saugumizavimas gali būti apibrèžtas kaip grėsmės konstravimo procesas.

\footnotetext{
${ }^{1}$ Ši frazè dažniausiai vartojama anglų kalba: „not consumer but also contributor“. Žr. pvz., Government Performance Report 2005. Prime Minister's statement, 200603 30, http://www.lrvk.lt/main en.php?cat=2\&d=4001, 20060419.

${ }^{2}$ Buzan B., Wæver O., Regions and Powers: The Structure of International Security, Cambridge: Cambridge University Press, 2003, p. 343

${ }^{3}$ Žr.: Miniotaite G., „The Baltic States: In Search of Security and Identity“, Krupnick Ch., ed., Almost NATO: Partners and Players in Central and Eastern European Security, Lanham Md.: Rowman \& Littlefield, 2003, p. 261-296.

${ }^{4}$ Buzan, B. „New Patterns of Global Security in the Twenty-First Century“, International Affairs 67 (4) 1991 , p. 432 (,the ability of states and societies to maintain their independent identity and the functional integrity against forces of change which they see as hostile").

${ }^{5}$ Būtent tokia saugumo samprata yra formuluojama $1996 \mathrm{~m}$. Lietuvos nacionalinio saugumo koncepcijoje. Žr.: „Lietuvos Respublikos nacionalinio saugumo pagrindų istatymas“, Valstybès žinios 2, 1997, p. 2-20. ${ }^{6}$ Žr.: Buzan B., Wæver O., de Wilde J., Security: A New Framework for Analysis, Boulder, CO: Lynne Rienner, 1997; Wæver O., „Securitization and Desecuritization“, Lipschutz R. D., ed., On Security, New York: Columbia University Press, 1995, p. 46-86.
} 
Faktiškai tam tikromis aplinkybėmis saugumizavimo objektu gali tapti bet kokia vidaus ar užsienio politikos problema (tautinis identitetas, migracija, „energetinè priklausomybè nuo vieno šaltinio“ ir t. t. $)^{7}$.

Minètas saugumo sampratos konceptinis nenuoseklumas jaučiamas beveik visuose Lietuvos saugumo politikos gaires nubrěžiančiuose dokumentuose bei politiniuose sprendimuose. Tai susiję su uždaviniais, kuriuos teko spręsti atsikūrusiai Lietuvos valstybei. Ji turëjo užtikrinti ne tik valstybès suvereniteto išsaugojimą, bet ir sudaryti palankias sąlygas esminiams teisiniams ir ekonominiams pokyčiams. Neatsitiktinai saugumo užtikrinimas buvo pagrindinè Lietuvos ir vidaus, ir užsienio politikos varomoji jẻga iki visiškos narystès ES ir NATO.

\section{Lietuvos saugumo ir gynybos politika kelyje i NATO ir Europos Sajunga: 1990-2004 m.}

1991 m. Lietuvai tapus Jungtinių Tautų nare, jos politinis elitas teoriškai turëjo galimybę rinktis iš kelių saugumo politikos krypčių: neutralumo, nedidelių valstybių sajungos ir prisijungimo prie daugiašalio stipraus karinio/ politinio aljanso. Visos trys galimybės turëjo savo šalininku ir priešininku, tačiau pirmoji ir antroji galimybės liko debatu lygmenyje, jos nebuvo institucionalizuotos, todèl toliau pagrindinį dėmesị skirsiu trečiojo pasirinkimo analizei.

Neutralumo ir Baltijos valstybių karinės sajungos idèjos daugiausiai dèmesio susilaukè 1990-1995 m. To laikotarpio ir užsienio, ir vidaus politika orientavosi ị tarpukario Lietuvos tautinės valstybės modelį. Užsienio ir saugumo politikos srityje jis gali būti apibūdintas kaip laviravimas tarp Maskvos ir Berlyno, siekiant susigrąžinti Lenkijos okupuotą (1920 m.) Vilniaus kraštą. Konfliktas dèl Vilniaus užkirto kelią susiformuoti stipriam Baltijos valstybiu aljansui, o $1939 \mathrm{~m}$. tarptautinio nestabilumo sąlygomis priimtas Lietuvos neutralumo įstatymas negalëjo užtikrinti valstybès saugumo. Mėginimas grižti prie šiu idejju atkūrus nepriklausomybę pasireiškẻ kai kurių tarpukario politikos stereotipu perkèlimu i naujai kuriamos valstybès politinę aplinką. Neatsitiktinai 1991-1992 m. tarpukario Lietuvos-Lenkijos santykių interpretacijos tapo įtampos tarp valstybių šaltiniu. Be to, šiuo laikotarpiu okupacinės Rusijos kariuomenès buvimas šalyje stabdè atvirai vakarietiškos saugumo politikos krypties pasirinkimą.

Bendru Lietuvos ir Vakaru valstybiu bei tarptautiniu organizaciju pastangų dẻka Rusijos kariuomenè iš Lietuvos buvo išvesta iki 1993 m. rudens. Tai sudare prielaidas $1994 \mathrm{~m}$. atvirai deklaruoti Lietuvos euroatlantinę

${ }^{7}$ Pasitelkę kalbos akto koncepciją, teorijos autoriai gana detaliai aprašo grèsmės konstravimo mechanizmą, tačiau tai nėra šio straipsnio tikslas. Detaliau apie saugumizavimą žr.: Williams M. C., „Words, Images, Enemies: Securitization and International Politics“, International Studies Quaterly 47 (4), 2003, p. 511-532. 
integraciją - narystę NATO ir ES - kaip pagrindinį Lietuvos užsienio ir saugumo politikos tikslą. Vakarietiškos saugumo politikos krypties pasirinkimas Lietuvos politikoje buvo siejamas su "grįžimu ị Europą", o narystė NATO ir ES buvo vertinama kaip negrižtamas integravimasis į Vakarus, saugantis Lietuvą nuo Rusijos pretenziju i jos suverenitetą.

Vakaru valstybiu atsakas ị iš esmès beveik visu posovietinès erdvès valstybiu siekimą narystės NATO ir ES buvo bendrų narystės kriterijų suformulavimas ir paskelbimas, kurie yra žinomi kaip Kopenhagos kriterijai (1993 m.) ir NATO plètros studija (Study on NATO Enlargement, 1995 m.). Tai panašūs kriterijai, jų esmę sudaro reikalavimas atitikti liberalios vakarų demokratijos principus. Kriterijai buvo papildyti sukuriant jų igyvendinimo kontrolès ir įvertinimo mechanizmą (veiksmu planai, progreso ataskaitos). Narystės NATO ir ES siekimo procesas tampa Lietuvos valstybės kūrimo pagal vakaru demokratijos modeli procesu, reikalaujančiu esminiu politinių ir ekonominiu reformų bei pokyčių saugumo ir gynybos politikoje.

Kaip bet koks meginimas racionaliai valdyti socialinius procesus, eurointegracija susiduria su valdomos medžiagos inercija, pasireiškiančia istoriniu stereotipu, jau susiformavusių socialinių identitetų bei nepasiteisinusių lūkesčiu pasipriešinimu. Vakaru pasaulis, ị kurị veržiasi Lietuva, nėra vienalytis; jame gana aiškiai išsiskiria socialiai orientuotas europietiškas gerovès valstybės modelis ir labiau reguliatyvine laisvos rinkos galia pasitikintis amerikietiškasis modelis. Siekiant greitesnio ekonominio efektyvumo, Lietuvoje ieškoma ju optimalios pusiausvyros. Per gana trumpą laiką buvo pasiektas įspūdingas ekonominis augimas ${ }^{8}$, tačiau jis yra lydimas socialinès atskirties didejimo, aukšto nedarbo lygio, sovietmečio nostalgijos. Tai sudare prielaidas politiniam nestabilumui, pasireiškiančiam „švytuokliniais“ rinkimais tarp kairès ir dešinės, parama populistinėms partijoms ir lyderiams, politiniam cinizmui, vedančiam prie korupcijos klestejjimo, ir galiausiai euroskepticizmui bei antiglobalizmui. Visos politinès jègos Lietuvoje sutaria, kad minèti reiškiniai kelia grèsmę Lietuvos valstybės vidiniam saugumui. Tai atsispindi ir saugumo politiką apibrèžiančiuose dokumentuose, juose socialinès atskirties mažinimas bei pilietinès visuomenès kūrimas laikomi svarbia valstybės saugumo prevencijos priemone.

Lietuvos saugumo ir gynybos politikoje narystès kriteriju atitikimas yra siejamas su gerais santykiais su kaimyninėmis valstybemis bei su kariniu pajėgumų vystymu pagal NATO standartus. Nuosekliai siekdama geru santykiu su kaimyninėmis valstybėmis, Lietuva, atmesdama tarpukario stereotipus, suartëjo su Lenkija, o nuo $1997 \mathrm{~m}$. mato ją kaip strateginę partnerę kelyje i NATO ir ES. Su Baltarusija, atsižvelgdama į ES poziciją Baltarusijos atžvilgiu po autoritarinio režimo įsitvirtinimo $1997 \mathrm{~m}$., Lietuva vykdo pragmatinę selektyvinio bendradarbiavimo politiką . Dvišalis bendradarbiavimas vystomas

\footnotetext{
${ }^{8}$ Lietuvos Statistikos departamento duomenis $2006 \mathrm{~m}$. Lietuvos BVP sudare vos $47 \%$ ES BVP vidurkio, tačiau dar 1997 m. jis tesudare 33 \%. Žurnalas Economist Lietuva, Estiją ir Latviją pavadino „Baltijos tigrais“. Žr.: „The Balts and the European Union“, The Economist, 12 December, 2002.

${ }^{9}$ Apie Lietuvos santykius su Baltarusija žr.: Lopata R., „Autoritarizmas Baltarusijoje: galimos grèsmès Lietuvos saugumui“, Lietuvos metiné strateginé apžvalga 2002, p. 201-214.
} 
tik tose srityse, kurios yra svarbios regiono saugumui ir stabilumui išsaugoti. Bendradarbiavimas apima valstybinès sienos demarkacijos, nelegalios migracijos, pasienio regionų bei energetikos klausimus.

Itakingiausia ir problemiškiausia Lietuvos kaimynė yra Rusija. Tai susiję ne tik su tuo, kad Rusija sunkiai susitaiko su SSSR žlugimu ir Baltijos valstybiu praradimu, bet ir su gana specifiniais jos santykiais su ES ir JAV. Siekdamos demokratizuoti Rusiją ir taip padaryti ją patikima energetinių resursų tiekimo bei kovos su terorizmu partnere, didžiosios vakarų valstybės (ypač Vokietija ir Prancūzija) buvo linkusios atsižvelgti į Rusijos pasipriešinimą Baltijos valstybiu narystei NATO. Tai atsispindëjo 1997 m. NATO viršūnių Madrido susitikimo sprendimuose, kai kaimynei Lenkijai buvo atvertos NATO durys, o Lietuva ivertinta tik kaip narystès siekianti valstybè.

Nors Rusija buvo priešiška Lietuvos transatlantinei integracijai, jos santykiai su Lietuva klostėsi geriau negu su kitomis Baltijos valstybėmis. Vienintele iš Baltijos valstybių Lietuva yra visiškai išsprendusi valstybinès sienos sutarties su Rusija klausimus ${ }^{10}$. Tai susiję ne tik su tuo, kad Rusija neturi Lietuvai pretenziju dèl rusų mažumos teisiu, bet ir su Lietuvos-Rusijos sienos specifika. Palyginti neilga Lietuvos sausumos siena su Kaliningrado sritimi yra ypač svarbi Rusijai ir visam regionui. Žlugus Sovietų Sajungai ir Lietuvai atkūrus nepriklausomybę, $1991 \mathrm{~m}$. Rusija prarado savo teritorinį vientisumą. Mažiausios ir labiausiai atsilikusios Kaliningrado srities ryšys su Rusija tapo priklausomas nuo jos tranzito (karinio, ekonominio, asmenu judejjimo) per Lietuvą sąlygu. Nenuostabu, kad Rusija siekia išsaugoti politinę ir ekonominę įtaką Lietuvoje.

Rusijos vertinimas Lietuvos saugumo politikoje keitesi priklausomai nuo NATO ir Rusijos santykių bei nuo ES politikos Šiaurès Rytu regiono atžvilgiu. Iš pradžiu militarizuota Kaliningrado sritis buvo suvokiama kaip tiesioginè karinė grèsmè Lietuvos nepriklausomybei. Ypač Kaliningrado grèsmès Lietuvai klausimas buvo aktualus $1994 \mathrm{~m}$. Jis keltas Baltijos Asamblèjoje, Lietuvos Vyriausybès programoje. Požiūris i Kaliningrado sriti, kaip i nuolatinės grėsmès Lietuvos nepriklausomybei šaltini, išreikštas ir Lietuvos Respublikos nacionalinio saugumo pagrindu istatyme, patvirtintame 1996 m. pabaigoje ${ }^{11}$. Laipsniškai šią "griežto" (angl. hard) saugumo poziciją pakeite „„svelniojo“ (angl. soft) saugumo reikalavimas: 2002 m. patvirtintoje Nacionalinio saugumo strategijoje Kaliningrado klausimas pateikiamas ne kaip grėsmė Lietuvos saugumui, o kaip „ekonominė, prekybinė ir kultūriné partneryste ${ }^{\prime \prime 12}$. Galima sutikti su studijos apie Kaliningrado sritį autoriais, kad „Lietuvos užsienio politikoje Kaliningrado sritis iš pagrindinės grėsmės saugumui 9-ajame dešimtmetyje transformavosi į privalumą - į galimybę vaidinti nepriklausomą pietryčiu Baltijos jūros regiono lyderio, realiai prisidedančio prie saugumo didinimo regione, vaidmenį ${ }^{\prime \prime 13}$.

\footnotetext{
${ }^{10}$ Lietuvos - Rusijos sienos sutartis buvo pasirašyta 1997 m. Lietuva ją ratifikavo 1999 m., Rusija 2003 m.

${ }^{11}$ Žr.: Lietuvos Respublikos nacionalinio saugumo pagrindų įstatymas, (nuoroda 5).

12 „Lietuvos nacionalinio saugumo strategija“, Vilnius, 2002.

${ }^{13}$ Sirutavičius V., Stanytė-Toločkienė I., „Rusijos Federacijos Kaliningrado srities strateginė reikšmé“,

Lietuvos metine strategine apžvalga 2002, Vilnius: Lietuvos karo akademija, 2003, p. 186.
} 
Lietuvai tapus NATO ir ES nare, jos santykiai su Rusija virsta ES ir Rusijos santykių dalimi. $2002 \mathrm{~m}$. pabaigoje pasirašyta ES ir Rusijos sutartis dèl Rusijos tranzito iš Kaliningrado anklavo per Lietuvos teritoriją paskatino Rusiją 2003 m. ratifikuoti ilgai delstą Lietuvos ir Rusijos valstybès sienos sutarti bei pasirašyti readmisijos sutartį. Nuo $2003 \mathrm{~m}$. liepos $1 \mathrm{~d}$. įsigaliojusios griežtesnès Kaliningrado srities gyventojų tranzito per Lietuvą taisyklès (vizų reikalavimas) priartino Lietuvą prie Šengeno sutarties erdvès, nesukeldamos pastebimo Lietuvos ir Rusijos santykiu pablogẹjimo. Kaliningrado sritis Lietuvos politikoje iš problemos virto "galimybių langu", atveriančiu regioninio bendradarbiavimo formų įvairovę. Lietuva pasirodè pajėgi kūrybiškai igyvendinti ES siūlomą bendradarbiavimo modeli. Tai turèjo įtakos jos savivokai regione. Lietuvos, kaip tilto tarp Rytų ir Vakaru, įvaizdị keité Lietuvos ir Vakarų placdarmo ir galiausiai - Vakaru vertybiu avanposto įvaizdžiai ${ }^{14}$.

Lietuva, siekdama tapti NATO ir ES nare, ne tik stropiai vykdè narystės reikalavimus, bet ėmėsi ir savarankiškų saugumo politikos iniciatyvu, praktiškai prisidėdama prie euroatlantinio saugumo ir stabilumo stiprinimo. $1997 \mathrm{~m}$. pradètos organizuoti regioninès Vilniaus konferencijos $2000 \mathrm{~m}$. subūrè narystės NATO siekiančias valstybes i „,Vilniaus devintuką", kuris 2001 m., prisijungus Kroatijai, virto „Vilniaus dešimtuku“" teroristų išpuolio „Vilnius-10“ tvirtai parėmè JAV. Dešimtuko valstybès prièmė bendrą pareiškimą, kuriame išreiškè solidarumą su JAV ir Aljansu. 2003 m. „Vilnius-10“ prièmė JAV politiką Irake palaikanti pareiškimą. Be to, dar iki oficialios narystės ES ir NATO Lietuva aktyviai įsijungè į ES Platesnés Europos Naujuju kaimynu politikos igyvendinimą, pretenduodama į lyderès vaidmeni perduodant ES kaimyninėms valstybėms (Baltarusijai, Ukrainai, Moldovai, pietų Kaukazo valstybėms) savo politinių ir ekonominių reformų patyrimą.

$2004 \mathrm{~m}$. Lietuvos saugumo politika, siejanti valstybės saugumą su naryste NATO ir ES, pasieke savo tikslą. Narystès siekimo procese kontūrus igavo pagrindinés Lietuvos saugumo politikos kryptys, keitėsi saugumo ir gynybos samprata priartedama prie NATO ir ES strateginiuose dokumentuose suformuluotų nuostatu. Tolimesnè Lietuvos saugumo politika tampa bendros ES užsienio ir saugumo politikos dalimi. Lietuvos politikai siekia, kad tai būtu gerai matoma dalis.

\section{Lietuvos saugumo politika po $2004 \mathrm{~m}$. NATO ir ES plètros}

Lietuvai tapus Europos Sajungos ir NATO nare, iškilo uždavinys naujai suformuluoti pagrindinius užsienio ir saugumo politikos tikslus bei surasti

\footnotetext{
${ }^{14}$ Žr.: Miniotaite G., „Convergent Geography and Divergent Identities: A Decade of Transformation in the Baltic States “, Cambridge Review of International Affairs 16 (2), 2003, p. 209-222.

${ }^{15}$ „Vilniaus dešimtuką̧“ sudaro Albanija, Bulgarija, Kroatija, Estija, Latvija, Lietuva, Makedonija, Slovakija, Rumunija ir Slovènija.
} 
savo vietą Europos Sajungos bendroje užsienio ir saugumo politikoje ${ }^{16}$. Siekiant narystės, Lietuvos, kaip ir kitų valstybių kandidačiu, tiek vidaus, tiek užsienio politika neišvengiamai buvo adaptacinè. Aiškiai suformuluoti narystės reikalavimai bei gerai apgalvotas ju igyvendinimo kontrolès mechanizmas nepaliko ypatingos erdvès kandidačių iniciatyvai. Kaip pažymima naujoje 2005 m. Nacionalinio saugumo strategijos redakcijoje, „Lietuvos Respublika savo nacionalinį sauguma suvokia kaip sudedamają šių organizaciju (NATO ir ES-G. M.) saugumo politikos dali ir remiasi NATO strateginès koncepcijos, Europos Saugumo strategijos, kitu NATO ir Europos Sajungos strateginiuose dokumentuose išdèstytų grèsmių analize, strateginiais tikslais ir veiklos priemonemis ${ }^{17}$.

Tačiau, kita vertus, „Vilnius-10“ veikla bei ankstyvas įsijungimas i Europos Sajungos kaimynystės politiką sukūrè prielaidas Lietuvos ambicijoms ,îtvirtinti mūsų šalị kaip regionų bendradarbiavimo centrą “18, tampant „aktyvia, matoma pasaulyje ir įtakinga regione valstybe "19. Pagrindžiant naujają Lietuvos užsienio ir saugumo politiką, atgaivinamas jau anksčiau šalies politiniame diskurse eksploatuotas "Lietuvos - regiono centro ir lyderès" įvaizdis. Faktiškai beveik visuose 2004-2006 m. su užsienio ir saugumo politika susijusiuose dokumentuose bei oficialiose kalbose pabrèžiama, kad Lietuva siekia tapti „aktyviu ir patraukliu bendradarbiavimo tarp regionu centru, skleidžiančiu euroatlantines vertybes, tolerancijos ir bendradarbiavimo dvasią, jungiančiu kultūras ir civilizacijas “20.

Pažymėtina, kad regionas, kurio centru ketina tapti Lietuva, jokiame dokumente ar oficialioje kalboje nėra apibréžiamas. Taip yra todėl, kad toks regionas faktiškai neegzistuoja, tai socialinis konstruktas, kurio formavimąsi ir turètų skatinti Lietuvos užsienio ir saugumo politika. Tokia regiono samprata yra artima naujojo regionalizmo teorijoms. Jose regionas suprantamas ne kaip bendra geografinè erdvè, o kaip bendra vertybinè erdvė, kurioje per ekonomini, politinị, kultūrinį ir karinį bendradarbiavimą gimsta regiono identitetas, sudarantis prielaidas Vakaru saugumo bendruomenès plètrai ${ }^{21}$. Regioninis identitetas nèra nacionalinių identitetų išvestinè, jo tapsmo pagrindas yra bendros normos ir vertybès, sukuriančios tai, ką Jurgenas Habermasas pavadino konstituciniu patriotizmu ${ }^{22}$. Lietuva, skatindama regioninį bendradarbiavimą ir

\footnotetext{
${ }^{16}$ Nekrašas E., „Lithuanian Foreign Policy: Concepts, Achievements and Predicaments“, Lithuanian Foreign Policy Review 2004, 2005, p. 28-37.

${ }^{17}$ Lietuvos nacionalinio saugumo strategija, 2005 m.sausio 20d. nutarimo redakcija, http://www.kam. 1t/index.php/lt/34381/, 20060911.

$182005 \mathrm{~m}$. Vyriausybès veiklos ataskaita, http://www.lrv.lt/13 vyr dok/LRV\%202005\%20ataskaitos\%20s antrauka\%20-\%20pilna.pdf, 20060819.

${ }^{19}$ LR Seimo rezoliucija dèl Lietuvos Respublikos užsienio politikos krypčiu Lietuvai tapus visateise NATO ir Europos Sajungos nare, 2004 m. gegužès 1 d., http://www.urm.lt/popup2.php?item_id=156, 200605 $25 \mathrm{~d}$.

${ }^{20}$ Dèl pagrindiniu valstybès užsienio politikos tikslu ir uždaviniu 2004-2008 m. Lietuvos politiniu partiju susitarimas, http://www.urm.lt/popup2.php?item_id=158,2006 $0620 \mathrm{~d}$.

${ }^{21}$ Adler E., Crawford B., Normative Power: The European Practice of Region Building and the Case of the Euro-Mediterranean Partnership, Berkeley: University of California, 2004.

${ }^{22}$ Habermas J., The Inclusion of the Other: Studies in Political Theory, Cambridge, Mass.: The MIT Press, 1998, p. 225-226.
} 
siekdama tapti jo varomaja jejga, drauge ji ir kuria. Lietuvos - regiono centro ir lyderès - sąvoka yra diskursyvinè konstrukcija, naratyvas, kuriuo grindžiama Lietuvos tarptautinè tapatybé ${ }^{23}$.

Kaip teigiama Nacionalinio saugumo strategijoje (2005 m.), Lietuva, plèsdama "laisvę ir demokratiją i kaimyninius Europos regionus“ bei konstruodama valstybès - politinès regiono lyderès - tapatybę, kartu sukuria prielaidas savo saugumui stiprinti. Tam ji gerina santykius su Ukraina, Moldova bei Pietu Kaukazo valstybėmis. Lietuva visiškai pritaria šių valstybių narystei NATO ir ES, praktiškai padėdama joms (daugiausiai Ukrainai ir Gruzijai) atitikti narystès šiose institucijose kriterijus. Lietuva tęsdama „pragmatinio selektyvinio bendradarbiavimo" politiką su Baltarusija sustiprino paramą šios šalies demokratinėms jègoms. $2005 \mathrm{~m}$. Baltarusijos prezidento rinkimuose Lietuva rẻmė opoziciją, suteikdama jai galimybę savo veiklą perkelti į Vilnių. Taip pat ị Vilniu persikèlè iš Minsko išvytas Europos humanitarinis universitetas. Tokie Lietuvos veiksmai sukèlè įtampą tarp valstybiu, Baltarusijos prezidentas apkaltino Lietuvos užsienio reikalų ministrą kišimusi į Baltarusijos vidaus reikalus. Bet Baltarusijos demokratizavimas, jos įtraukimas į ES kaimynystės politiką išlieka svarbiu Lietuvos saugumo politikos uždaviniu.

Dalyvaudama ES naujuju kaimyniu politikoje Lietuva savo pagrindiniu uždaviniu laiko Rytų dimensijos sustiprinimą. Tai buvo svarbiausias 2006 m. Vilniaus tarptautinės konferencijos "Bendra vizija bendrai kaimynystei“ akcentas $^{24}$. Konferencijoje buvo atkreiptas demesys i „išaldytus konfliktus" Moldovoje, Gruzijoje, Kalnų Karabache ir Čečènijoje bei pabrèžiama, kad NATO ir ES turètų būti aktyvesnès juos sprendžiant. Visi minèti konfliktai yra susiję su Rusijos interesais buvusioje sovietinëje erdvëje. Kai kurių komentatoriu požiūriu, ,„̌̌̌aldytų konfliktų internacionalizavimas, taip pat JAV viceprezidento Richardo B. Cheney kalba, kurioje jis apkaltino Rusiją naudojant dujas ir naftą kaip „bauginimo ir šantažo instrumentus, siekiant manipuliuoti tiekimu ir monopolizuoti tranzito kelius“25, suteikè konferencijai antirusišką pobūdį.

Kyla klausimas, ar pakito Lietuvos-Rusijos santykiai Lietuvai tapus ES ir NATO nare? Ar išliko Rusijos saugumizavimo (securitization) tendencijos? Pirmiausiai, kaip buvo minèta, Lietuvos sienai su Rusija tapus išorine ES siena, daugelis svarbių klausimų (pvz., vizų, sienos kontrolès) virto dvišaliu ES-Rusijos santykių klausimais. Lietuvoje tai sukẻlè dvejopą reakciją: tautiškai nusiteikusios politinės jẻgos įžvelgia grèsmę Lietuvos suverenitetui, kuri slypi prorusiškose ES nuostatose. Tačiau iš esmès vyrauja nuomonè, kad narystė ES ir NATO visiškai eliminuoja karinę Rusijos grėsmę. Nepaisant to, Rusijos saugumizavimas užima svarbią vietą Lietuvos politikoje. Nuolat grịžtama prie

\footnotetext{
${ }^{23}$ Plačiau žr.: Miniotaitė G., ,Europos normatyvinė galia ir Lietuvos užsienio politika“, Politologija 43 (3), 2006, p. 3-19.

${ }^{24}$ Konferencijoje dalyvavo Lietuvos, Lenkijos, Moldovos, Rumunijos, Gruzijos, Ukrainos, Bulgarijos, Latvijos ir Estijos prezidentai. Taip pat konferencijoje dalyvavo JAV viceprezidentas Richard B. Cheney ir ES bendros užsienio ir saugumo politikos vadovas Javier Solana.

${ }^{25}$ Remarks by Vice President of the United States Richard B. Cheney at the Vilnius conference, May 4, 2006, (,instruments of intimidation and blackmail in order to manipulate supplies and monopolize transit routes“, http://www.vilniusconference2006.lt/sen/lib.download/15, 20060820.
} 
Rusijos atsakomybės dèl Lietuvos okupacijos ir jos sukeltų tragiškų pasekmiu klausimu, baiminamasi ne tik energetinès priklausomybės nuo Rusijos, bet ir destabilizuojančios Rusijos slaptujų tarnybų įtakos šiuolaikinei Lietuvos vidaus politikai. Toks Rusijos traktavimas virsta konkrečiais sprendimais: Lietuvos Prezidento atsisakymu priimti Rusijos prezidento kvietimą dalyvauti 60-ies metu pergalės prieš hitlerinę Vokietiją minëjime Maskvoje (2005 m.), diplomatine parama Gruzijai užsitęsusioje įtampoje su Rusija, europarlamentaro Vytauto Landsbergio pasiūlyta deklaracija Europarlamentui ${ }^{26}$, kurioje primenama apie Rusijos (Sovietų Sajungos) atsakomybę dèl milijonų prarastų gyvybių.

Lietuva kartu su kitomis Rytu Europos naujokèmis siūlo senosioms Europos valstybėms blaiviai pažvelgti į Rusiją, liautis romantizuoti jos gaivališkumą ir neprognozuojamumą, o įvertinti potencialius pavojus, slypinčius demokratijos apribojimuose bei imperinėse ambicijose. Kaip rodo R. Cheney kalba Vilniaus konferencijoje, JAV išgirdo šį ES naujokių raginimą. Dar siekdama narystès ES ir NATO, Lietuva pasirodè kaip proamerikietiška valstybė, tai aiškiai pademonstravo Vilnius-10 grupès pritarimas visiems JAV veiksmams kovoje prieš terorizmą bei lietuvių karių dalyvavimas Irako kare. Lietuvos politikai gana vieningai nepritaria Europos ir Amerikos požiūrių i tarptautinį saugumą supriešinimui, ižvelgdami jame grèsmę Lietuvos saugumui. Kaip pažymima Baltojoje Lietuvos gynybos politikos knygoje (2006 m.), ,,stiprus transatlantinis ryšys tarp JAV ir Europos yra esminè Lietuvos ilgalaikio saugumo sąlyga “27. Apskritai galima teigti, kad ir saugumo konceptualizavimas, ir saugumo politika Lietuvoje vystosi globalaus saugumo igyvendinimo kryptimi. Tai rodo ir Lietuvos gynybos politikos raida.

\section{Naujoji Lietuvos gynybos politika}

Lietuvos gynybos politika, tapusi kolektyvinès gynybos dalimi, orientuojasi į du pagrindinius uždavinius - saugios aplinkos kūrimą ir ị jos išsaugojimą. Pirmojo uždavinio igyvendinimas remiasi Europos saugumo strategija, antrojo - NATO strateginèms nuostatomis. Lietuvos politikoje ES ir NATO turi skirtingą reikšmę, ES yra traktuojama kaip normatyviné, pilietinė galia, kuri, anot Andrew Moravcsikio, priklauso „ne nuo batalionų ir bombu kiekio didinimo", bet nuo "taikaus demokratijos skatinimo, plečiant prekybą, užsienio pagalbą bei taikos palaikymą “28. Tuo tarpu NATO pirmiausiai yra siejama su saugumo, grindžiamo karine galia, užtikrinimu. Pilietinès ES galios papildymas karine galia Lietuvoje vertinamas teigiamai, tačiau po karo Irake išryškejjusi tendencija sumenkinti NATO, kaip transatlantinio forumo, reikšmę Lietuvos politikams atrodo nepakankamai apgalvota. Sprendžiant

\footnotetext{
${ }^{26}$ Europarlamentaru Vytauto Landsbergio, Bronislaw O. Geremeko, Valdis Dombrovskio, Toomas Hendrik Ilveso „Deklaraciją dèl 1939 m. rugsèjo 17 d. paminèjimo“ (Declaration on the anniversary of 17 September 1939) pasirašè apie 80 parlamentarų, tačiau to neužteko, kad ji būtų priimta.

${ }^{27}$ Baltoji Lietuvos gynybos politikos knyga, Vilnius: Krašto apsaugos ministerija, 2006.

${ }^{28}$ A. Moravcsik, ,,The Quiet Superpower”, Newsweek, 2002, June 17-27, 2002, p. 12.
} 
pagal naujausių Lietuvos strateginių dokumentų turinị, jie visiškai pritaria dar 1998 m. JAV valstybės sekretorès Madeleine Albright suformuluotai idejjai kaip išvengti triju " "D“ , kurie išreiškẻ JAV poziciją Europos gynybos politikos atžvilgiu: „no duplication of what was done effectively under NATO, no decoupling from the US and NATO, and no discrimination against non-EU members “29. Baltojoje knygoje (2006 m.) pabrěžiama, kad transatlantinio ryšio stiprinimas yra vienas iš pagrindiniu gynybos politikos uždaviniu , jos formulavime ryškūs visi 3 „D", ypač pirmasis ir antrasis, jie performuluoti kaip „pajégumų nedubliavimo principas“ ir kaip „nauji pajègumai, o ne naujos institucijos “30.

Nors ir tapusi bendromis taisyklemis reguliuojamos visumos dalis, Lietuvos saugumo politika išsaugo savarankiškumą ir iniciatyvumą panaudodama savo unikalų integracijos patyrimą įsitvirtinti naujoje erdvejje. Galima sakyti, kad saugumo politikoje Lietuva ne tik vykdo ES bendros užsienio ir saugumo politikos nuostatas, bet ir mėgina daryti joms įtaką, ypač siekdama sustiprinti rytinę ES saugumo politikos kryptị. Siekdama tapti politiniu regiono centru, ji jaučiasi pakankamai pajègi prisidèti prie Europos normatyvinès galios stiprinimo. Kiek kitoks yra Lietuvos požiūris i gynybos politiką, kuri buvo ir tebėra siejama su NATO. $1994 \mathrm{~m}$. ịsijungusi i narystès NATO siekimo procesą, ji iš esmés keite gynybos politikos nuostatas, derindama jas prie NATO saugumo strategijos pokyčių. Galima sakyti, kad Lietuvoje beveik nebuvo kvestionuojama nei NATO strategija, nei jos reikalavimai.

Rimčiausias iššūkis Lietuvos gynybos politikai, pareikalavęs ginkluotuju pajėgu reformos, yra perëjimas nuo teritorinès prie kolektyvinės gynybos ir kriziu įveikimo koncepcijos. Lietuvos teritorinès gynybos koncepcija, grindžiama totalios ir besąlygiškos gynybos principu, visiškai atitiko Lietuvos politikos orientaciją į tautinès valstybès kūrimą. Šios koncepcijos rẻmuose NATO pirmiausiai buvo siejama su 5 straipsniu, jam buvo skiriamas Lietuvos teritorijos neliečiamumo garanto vaidmuo. Tokia NATO samprata neprieštaravo Lietuvos teritorinės gynybos koncepcijai, suformuluotai 1996 m. Nacionalinio saugumo įstatyme. Pastebimi pokyčiai prasidëjo po to, kai 1999-2001 m. Lietuva pradejo vykdyti valstybèms kandidatėms skirtus NATO veiklos (action) planus. Pereinama nuo grèsmiu samprata grindžiamos gynybos politikos prie pajegumais grindžiamos gynybos koncepcijos.

2004 m. Lietuvos karinejje strategijoje jau visiškai aiškiai įtvirtinamos kolektyvinės gynybos nuostatos: „Lietuvos kariuomenės pajėgumai plètojami pagal tokius prioritetus, kurie stiprina viso aljanso kolektyvinę gynybą ir pasirengimą, prisideda prie atitinkamų Jungtinių Tautų ir Europos Sajungos

\footnotetext{
${ }^{29}$ M. Albright, „The Right Balance Will Secure NATO’s Future“, Financial Times, 7 December, 1998. (,nedubliuoti NATO pasiekimu, (gynybos srityje - G. M.), neprarasti ryšio su JAV ir NATO (sprendimų prièmimo srityje - G. M.), nediskriminuoti ne ES narių“).

${ }^{30}$ Baltoji knyga, (note 27) p. 8.

2006 m. rugpjūčio mèn. priimtame Baltijos valstybių gynybos ministrų bendrame komunikate pabrèžiamas poreikis stiprinti NATO ir ES politinį dialogą ir užtikrinti jų glaudų bendradarbiavimą planuojant ir vystant karinius pajėgumus. Žr.: http://www.kam.lt/index.php/en/105132/, 20060912.
} 
greito reagavimo pajėgų stiprinimo “31. Atitinkamai keičiasi Lietuvos ginkluotuju pajègų tikslai - ju planavimas orientuojamas į dalyvavimą su penktu straipsniu nesusijusiose operacijose ne tik euroatlantinëje erdveje, bet ir už jos ribų ${ }^{32}$. Prioritetine kryptimi yra laikoma greito reagavimo brigados kūrimas, kuri iki 2015 m. būtu pajègi dislokuoti vieną pėstininkų batalioną. Kaip dažnai kartoja aukšti Lietuvos pareigūnai, „ginkluotosios pajègos turi būti pritaikomos sprendžiant terorizmo sukeltas problemas bet kurioje pasaulio vietoje. Lietuvos gynyba prasideda Afganistane, o ne Lietuvos teritorijoje “33. Tačiau, kaip pažymi Krašto apsaugos ministerijos sekretorius Renatas Norkus, tokios sąvokos, kaip kriziu valdymas, tolimos Afganistano provincijos rekonstrukcija ar taikos palaikymas, sunkiai skinasi kelią į Lietuvos viešąją nuomonę. Gyventojams atrodo nepateisinama laikyti kariuomenę tam, kad ji gesintų mišku gaisrus ar valytų aplinką: kareivis praranda tautos ir šalies gynëjo įvaizdi. Darosi vis sudètingiau išlaikyti visuomenès paramą bei pateisinti didesnio finansavimo būtinybę. "Sudètingiausia yra pakeisti mąstymą: pradèti galvoti apie Aljanso, o ne tik Lietuvos kolektyvinę gynybą“34.

\section{Lietuva ir Europos gynybos politika}

Kaip buvo minėta, Lietuvos gynybos sistema pirmiausiai vystosi kaip NATO gynybos sistemos dalis. Savo saugumą Lietuva sieja su tvirtais transatlantiniais santykiais tarp JAV ir Europos. 2004 m. sustiprëję ES mėginimai kurti autonominę Europos gynybą Lietuvoje nesulaukè nei entuziastingo pritarimo, nei atviros kritikos. Lietuva, pritardama Europos gynybos agentūros įsteigimui ir veiklai, Europos karinių pajėgumų didinimą priima kaip NATO sustiprinimo priemonę. Planuojama kartu su Vokietija, Slovakija ir Latvija prisijungti prie Lenkijos vadovaujamos ES kovinès grupès, kuriai Lietuva priskirs vieną pėstininkų kuopą ir paramos elementus. Tačiau tarptautinį saugumą Lietuva sieja su NATO pajègų stiprinimu. Tai akivaizdžiai iliustruoja jos dalyvavimas tarptautinėse karinėse operacijose 2006 m. (žr. lentelę).

\footnotetext{
${ }^{{ }_{11}}$ Lietuvos Respublikos karinè strategija, patvirtinta 2004 m. lapkričio 15 d. http://www.kam.lt/index. php/lt/34381/, 20060905.

${ }^{32}$ Naujausią informaciją apie Lietuvos karių dalyvavimą NATO, ESBO, JT rengiamose tarptautinėse operacijose žr. Lietuvos krašto apsaugos ministerijos svetainėje: http://www.kam.lt/index.php/lt/104524/.

${ }^{33} \breve{Z r}_{\text {r: }}$ R. Norkus, Defense Transformation: A Lithuanian Perspective. 11 April 2006, Garmisch-Partenkirchen, Germany. http://www.kam.lt/index.php/lt/96062/, 20060915.

${ }^{34}$ Ten pat.
} 
Lentelè. Lietuvos dalyvavimas tarptautinèse karinèse operacijose $2005-2006$ m.

\begin{tabular}{|c|c|c|c|}
\hline Operacija & $\begin{array}{c}\text { ESGP } \\
\text { operacijos }\end{array}$ & NATO operacijos & $\begin{array}{c}\text { JAV } \\
\text { (koalicijos) } \\
\text { vadovaujamos } \\
\text { operacijos }\end{array}$ \\
\hline $\begin{array}{l}\text { ES operacija ALTHEA } \\
\text { Bosnijoje }\end{array}$ & 1 karys & & \\
\hline $\begin{array}{l}\text { ESBO paramos apmokant } \\
\text { Gruzijos pasieniečius } \\
\text { programa }\end{array}$ & $\begin{array}{l}1 \text { karinis } \\
\text { specialistas }\end{array}$ & & \\
\hline $\begin{array}{l}\text { KFOR operacija „Joint } \\
\text { Guardian“ Kosove }\end{array}$ & & $\begin{array}{l}30 \text { karių būrys, } \\
\text { rotacija kas pusė metų } \\
\text { (Priština), Lenkijos } \\
\text { bataliono sudètyje, } \\
2 \text { kariai KFOR štabe } \\
\text { (Kačanikas) }\end{array}$ & \\
\hline $\begin{array}{l}\text { ISAF } \\
\text { Taikos ịvedimo misija } \\
\text { Afganistane }\end{array}$ & & $\begin{array}{l}\text { Lietuvos vadovaujama } \\
\text { provincijos atkūrimo } \\
\text { grupé Čagčarane - } 123 \\
\text { kariai, } 4 \text { štabo karininkai } \\
\text { (Heratas), } 2 \text { štabo } \\
\text { karininkai (Kabulas) }\end{array}$ & \\
\hline $\begin{array}{l}\text { NATO mokymo misija } \\
\text { Irake }\end{array}$ & & 6 kariai & \\
\hline $\begin{array}{l}\text { Humanitarinè operacija } \\
\text { Pakistane }\end{array}$ & & 10 specialistų & \\
\hline $\begin{array}{l}\text { Koalicijos vadovaujama } \\
\text { karinè operacija Irake ,Iraqi } \\
\text { Freedom‘ }\end{array}$ & & & $\begin{array}{l}56 \text { kariai, } 3 \\
\text { štabo karininkai }\end{array}$ \\
\hline $\begin{array}{l}\text { Operacija ,Enduring } \\
\text { Freedom‘ Afganistane }\end{array}$ & & & $\begin{array}{l}1 \text { štabo } \\
\text { karininkas }\end{array}$ \\
\hline
\end{tabular}

Šaltinis - Lietuvos krašto apsaugos ministerija, 2006 m.

Iš lentelès matyti, kad ESGP operacijose 2006 m. dalyvauja tik du Lietuvos kariai. Gerokai daugiau dėmesio skirta Lietuvos ekspertu dalyvavimui įvairiuose konfliktuose. Lietuvos ekspertai siųsti į tokias Europos Sajungos misijas, kaip teisės viršenybės misija Gruzijoje, sienos monitoringas Moldovos ir Ukrainos pasienyje ir Gruzijoje. Taip pat Lietuva remia Europos Sajungos siekị prisidèti prie krizių valdymo ne tik kaimyniniuose, bet ir tolimesniuose regionuose. 2005 m. Lietuvos ekspertai dalyvavo Europos Sajungos misijose 
Indonezijoje, Palestinoje, taip pat rengiant Irako teisėsaugos pareigūnus. Iš viso Europos Sajungos civilinèse misijose $2005 \mathrm{~m}$. dalyvavo 17 ekspertu , o rinkimu stebëjimo misijose -33 stebètojai iš Lietuvos ${ }^{35}$.

Pagrindinis Lietuvos kariu kontingentas dalyvauja su NATO ir JAV vèliava vykstančiose tarptautinèse operacijose. Tai dar kartą patvirtina, kad Lietuva NATO ir ES gynybos politiką traktuoja kaip papildančias ir sustiprinančias viena kitą. Tačiau Lietuvai kelia nerimą kai kurios Europos gynybos politikos tendencijos bei jos tolimesnè raida. Kaip pažymi Kęstutis Paulauskas, neramina tai, kad ES kariniai standartai bei gynybos planavimo sistema gali skirtis nuo NATO. Tai reikštu, kad Lietuvos gynybos sistemos kūrimas pagal NATO karinius standartus nueitu perniek. Be to, ryškëjantis NATO ir ES kariniu struktūru dubliavimas verčia skaidyti ị dvi dalis ir taip gana menkas Lietuvos gynybos pajègas. Nerimą kelia ir Europos gynybos agentūros veikla. Agentūros planai sukurti bendrą ginklu pirkimo politiką nẻra palankūs Lietuvai. Jos rekomendacija pirkti europietišką ginkluotę gali pabloginti jau nusistovejjusias gana palankias ginklu pirkimo iš JAV sąlygas ${ }^{36}$. Lietuva siekia, kad Europos ginklu pirkimo politika liktų atvira transatlantiniam bendradarbiavimui.

\section{Baigiamosios pastabos}

"Ne tik naudotoja, bet ir pagalbininkè", - ši frazè, vartojama daugybëje oficialių dokumentų, aukštų pareigūnų kalbų ir pasisakymų konferencijose, trumpai ir koncentruotai išreiškia oficialią Lietuvos saugumo ir gynybos politikos poziciją jai tapus ES ir NATO nare. Tačiau ar patvirtino straipsnio turinys šią ambicingą nuostatą?

NATO ir ES Lietuvos politiniame diskurse iš pat pradžių turëjo dvejopą interpretaciją - instrumentinę ir normatyvinę. Siekiant narystės NATO, vyravo instrumentinè Aljanso interpretacija, pirmiausiai NATO buvo skiriamas skydo, apsaugančio Lietuvą nuo neprognozuojamos grèsmės iš Rytų, vaidmuo. Daug didesnị simbolinị krūvị turèjo ES. Tai tarsi istorijos verpetuose prarastas El Dorado, grižimas i ji reiškia ne tik valstybès sauguma, bet ir vakarietiškos tapatybès susigrąžinimą. Neatsitiktinai narystès ES siekimo proceso konceptualizacijoje vyrauja kelio, grižimo į Europą metaforos. Ir ES, ir NATO narystės kriterijų tenkinimas bei derybu procesas vede prie visapusiškos valstybės ir visuomenès transformacijos. Saugumo politikoje tai pasireiškè kaip negatyviu nuostatų kaimyninių valstybių atžvilgiu įveikimas bei kaip perëjimas prie bendro saugumo sampratos. Tai savo ruožtu sąlygojo pokyčius gynybos

\footnotetext{
${ }^{35}$ Lietuvos Respublikos Vyriausybès 2005 metu veiklos ataskaita, 2006 m. kovo 30 d., http://www.lrv. $1 \mathrm{t} /$ main en.php?cat $=2 \&$ script $=1$

${ }^{36} 2001-2003$ m. Lietuva iš JAV įsigijo 75 prieštankines raketas, 60 raketų žemè-oras, 8 paleidimo ịrenginius, 15 Humvees. Žr.: Paulauskas K., „The Baltics: from nation states to member states“, Occational Paper 62,2006, p. 38 .
} 
politikoje, perëjimą nuo teritorinės prie kolektyvinės gynybos koncepcijos bei ginkluotuju pajègų reformą.

Lietuvai tapus NATO ir ES nare, jos saugumo ir gynybos politika praranda buvusį vientisumą - ji skyla į užsienio ir saugumo politiką ir į gynybos politiką. Pirmoji yra siejama su Europos normatyvinès galios plètra, kurios esmę gana vaizdingai išreiškia ES strategijos pavadinimas: „Saugi Europa geresniame pasaulyje" (angl. A secure Europe in a better world). Prisidedama prie jos tikslu igyvendinimo, Lietuva imasi ambicingo lyderès vaidmens, skleisdama politinių ir ekonominių reformų patyrimą į kaimynines rytų šalis. Kasmetinès Vilniaus konferencijos tapo forumu, vienijančiu narystės ES ir NATO siekiančias posovietinės erdvès valstybes.

Lietuvos gynybos politika yra plètojama kaip NATO politikos dalis. Pagal savo galimybes prisidėdama prie NATO strategijos igyvendinimo, Lietuva siekia tapti patikima Aljanso nare. Savo ypatingą vaidmeni Aljanse ji sieja su aktyviu Lietuvos dalyvavimu NATO plètros į Rytus procese.

Lietuva palaiko karinès ES dimensijos stiprinimą, tačiau nepritaria galimam ES ir NATO funkcijų ir pajėgumų dubliavimui, savo saugumą siedama su tvirto transatlantinio ryšio išlaikymu.

Atsakant į klausimą, ar pagrịstos Lietuvos ambicijos vaidinti pastebimą vaidmenį ES saugumo ir gynybos politikoje, būtų dvejopas. Lietuva aktyviai ir kūrybingai įsijungè i ES saugumo strategijos iggyvendinimą, siekdama suteikti didesnį svorị jos rytinei dimensijai. Tačiau jos dalyvavimas stiprinant ES karinę dimensiją kol kas yra greičiau simbolinis. 